of the south-west monsoon, vessels can run for shelter into their midst, and once there are as safe as when inside a breakwater. If the surface is so still, of course so is the water bilow, and such spots seem to be well suited to the siluroid fishes. These curious patches of sea which appear in a continually perturbed state, and the sea-bottom in the locality, would probably well repay careful scientific observation.

Trie manufacture of isinglass, generally supposed to be confined to Russia and North America, or other countries where the sturgeon is found in abundance, is carried on to a considerable extent in India, principally from the air-vessels of several varieties of acanthopterygian fishes, and particularly, different kinds of perch, as well as from other fish. There is room for a great extension of the trade, as isinglass, the purest known form of animal jelly, has, in a measure, had its consumption checked by its high price, and substitutes are employed, such as gelatine, of which it is itself the purest form.

Ax the last meeting of the British Association a committee was appointed to investigate the circulation of the under. ground water in the New Red Sandstone and Permian Formations of England, and the quantity and character of the water supplicd to the various towns and districts from these formations. Prof. IIull, M.A., F.R.S., director of the Geological Survey of Ireland, is chairman, and Mr. C. E. de Rance, F.G.S., Scientific Club, 7, Saville Row, London, W., secretary. The fullowing queries have been circulated by the committee for the purpose of eliciting information in connection with the important subjcct:-1. Position of well, or wells, with which you are acquainted. 2. Approximate height of the same above the meas sea level. 3. Depth from surface to bottom of shaft of well, with diameter. Depth from surface to bottom of bore-hole, with diame. ter. 4. Height at which water stands before and after pumping. Number of hours elapsing before ordinary level is restored, aiter pumping. 5. Qukaztity capable of being pumpect in gallons per day. 6. Dues the water level vary at differeat seasons of the year, and how? Ilas it diminished during the last tea years? 7. Is the ordinary water level e ter affected by local rains, and if so, in how short a time? And how does it stand in regard to the level of the water in the neighbouring streans, os sea? 8. Analysis of the water, if any? Does the water possess any maxked pecticiarity? 9. Nature of the rock passed through, including cover of arift, with thichutsses. 10. Does the cover of drift over the rock contain surface springs. II. If so, are they

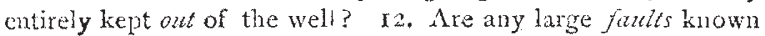
to exist close to the well? I3. Were any salt springs or brine wells passed through in making the well? 14 . Are there any sall springs in the neighbourhood? I5. Have any wells or borings been discontinued in your neighboumood, in consequence of the water being more or less biackish? If so, if possible, please give section in reply to query No. 9.

WE have received, among the results of the greographical and geological explorations of the Western (U.S.) States, the annotated list of the birds of Utah, by Mr. H. W. Henshaw, containing the names of 214 species, of which 160 were either taten or noted in the expedition. The author thinks that if collections were, as they have not yet been, made during the spring months, several extra species would have to be added to the collection.

CoAL is beginning to attract attention in New South Wales, in some parts of which the mineral is being found in abundance, and the pre-eminence which go!d and cspper have maintained will be assailed by the increasing importance of the newly workel product. A sean, seven feet thick, has been opened at B:oughton Creek, near the Shoalhaven River, and not far from the Moss Vale Railway Station; so that every circumstance of locality is in favour of its profitable working.

THE American Chemist for August and September, which we have just received, contains a full account of the proceedings at the Priestley Centenary in Northumberland, Pa., on July $3 \mathbf{r}$ last. There was then a large and enthusiastic gathering of men of science and others, and several valuable addresses were given. The principal one in the numbers before us is by Prof. B. Silliman, being a long, minutely detailed, and carefully compilea paper on "American Contributions to Chemistry."

WE are gratilied to see that the Geosraphical Magazine has been so successful that the price is to be reduced to one shilling.

The additions to the Zoological Society's Gardens during the past week include a Chamois (Ruficapra traşus) from the Pyrenees, presented by Mr. A. Wilson; a White-fronted Capuchin (Cebus albitrons) from South America, presented by Mis. Carpenter; a common Boa (Boa constrictor) from South America, presented by Capt. E. C. Kemp; two Barred-tailed Pheasants (Phasionus recusii) from North China, received in exchange.

\section{ON THE STRUCTURE OF STIGMARIA*}

$A^{T}$ a meeting of the Manclester Literary and Philosophical Society, held on October $20, \mathrm{Mr}$. Binney called in ques. tion some conclusions at which I had arrived and had published in Part II. of my memoirs on the Structure of the Coal Plants, respecting the organisation of Stigmaria. Mr. Binney further published an abstract of his remarks in Part II. of vol. xiv. of the Society's Proceedings. Believing that Mr. Binney's observations, if allowed to pass unnoticed, may mislead some palæontologists unacquainted with Stigmaria, I feel called upon to reply to them through the same channel as that which he has employed for their promulgation. The general features of the plant known for half a century as Stigmaria ficoiles have been so well described by Lindley and Hutton, Dr. Hooker, Mr. Binney, and Brongniart, that no one familiar with those descrlptions can fail to recognise it without difficulty. That plant consisted of a central medulla, surrounded by a cylinder of scalariform vessels arranged in radiating wedges, very distinctly separated by two linds of medullary rays (primary and secondary), the whole being enclosed in a thick bark, from the surface of which spring numerous large cylindrical rootlets. The vascular cylinder gives off numerous large vascular bundles of scalariform vessels, which proceed outwards, through the conspicuous primary medullary rays, to reach the rootlets.

The dispute between $\mathrm{Mr}$. Binney and myself resolves itself chiefly into three points: (1), the structure of the medulla of Stigmaria; (2), the source whence the vascular bundles supplying them are dexived; and (3), the nature of some vascular bundles which both $M:$. Binuey and $M$. Goeppert have figured as existing within the medulla, and one of which is prolonged radially in M. Goeppert's example through a medullary ray. Mr. Iinney and M. Goeppert believe that the cellular medulla of Stigmaria contained bundles of very large scalariform vessels, and that those bundles proceeded outwards to supply the rootlets. On the other hand, in my second memoir, reforred to by Mr. Binney, I not only expressed my conviction, but demonstrated the absolute certainty, that such was not their origin. I adhere to the same opinion as I previously expressed, and have the specimens on the table which prove its correctness. The fact that these bundles were derived not from the medulla, but from the vascular wedges of the woody cylinder, was illustrated by the figures 43,44 , and 47 of the memoir referrel to, figures which acculately represent, not conditions occasionally met with, but those which characterise every specinen of the true Stismaria ficoides. In the memoir I further affirm that immediately within the woody cylinder there exists a delicate cellular tissue, and state that one of my specimens makes it perfecly clear that the entire nedulla consisted of similar cells, unmixed with any vascular bundles whatever such as were represented in M. Goeppert's and Mr. Binney's figures, and the accuracy of which is, was, and it appears still is, endorsed by Mr. Binney. After thus endorsing what $I$ bel leve to be a grave mistake, Mr. Binney proceeds to justify his doing so by appealing to a specimen which $I$ have not seen, but which Mr. Einney's own description convinces me is a plant altogether different alike from the Stigmaria of authors, and from $M$. * A paper read before the Manchester Philosophical Society, by Prof. W.
C. Williamson, F.R.S., Nov. 17 . 
Gocppert's and Mr. Binney's own figures. Mr. Binney's describes his new specimen as having a radiating woody cylinder, immediately within which is a second series of large ressels not arranged in radiating wedges, and which Mr. Binney says is "something like a mcdullary sheath, enclosing a medulla composed of very small and short barred tubes or utricles, in which are mingled large vascular tubes or utricles." Though this use of vague terms renders the sence obscure, I presume that Mr. Binney simply means that in the medulla of his plant a vascular cylinder cncloses a cellular medulla, or, in other words, that his specimen bus a Diploxyloid axis. That $\mathrm{Mr}$. Binney possesses a specimen having the alove structure, and giving off rootlets from its periphery, I have no reason for doubting, since in the $m \in$ moirs already quoted I have described a similar structure under the name of Diploxylon stismarioideum, and respecting which I make the following observations:- "It is possible that the plant may, like Stigmaria, prove to be the uppermost part of a root of some of the other forms" (i.c. of Lepidodendroid stems), "though I have never yet found it associated with any rootlets, and it may be a fragment from the base where stem and roots united" (loc. cit. p. 239). I arrived at the above conclusions because $I$ found in the specimen described, evidence that large rootlct bundles were given off from the woody zone as in the true Stigmaria. But I affirm that out of hundreds of Stigmarian fragments that I have examined, I have only found two possessing this structure, and I unhesitatingly express my conviction that Mr. Binney's specimen is another example of an equally rare type, both being entirely distinct from Stigmaria ficoides, to which latter plant alone is referable Mr. Binney's previously pub. lished figures, M. Goeppert's description and figures of which Mr. Binney approves, and mine which he rejects.

Mr. Binney proceeds to say: "The size of these large vascular tubes or utricles in the medulla exceeding anything so far as his knowledge extended, hitherto observed in fossil plants, shows that it was easily decomposed, and thus accounts for the general absence of the medulla in Sigillaria and its roots." To this reasoning I must altogether demur. Size has nothing whatever to do with the preservation of the tissues in fossil plants. Vascular structures strengthened by transverse bars of lignine are equally well preserved, whether they are large or small. The medulla of Stigmaria disappearerl or became much disorganised because it consisted of an unusually delicate cellular tissue with extremely thin walls. This tendency to decay was more manifest towards the centre of the medulla than at its circumference. Specimens on the table exhibit this peripheral part of the cellular medulla in exquisite perfection, giving off its characteristic cellular prolongations constituting the medullary ray $\mathrm{s}$, as described in my memoir. And yet this beantiful cellular tissue occupies the position which Mr. Binney says was occupied by "large vascular tubes or utricles." The specimens referred to showing these conditions constitute unanswerable facts.

Mr. Binney correctly notes the resemblance of the inner vascular cylinder in his specimen to his "medullary sheath." I have already said the same thing in several of my memoirs, and M. Brongniart said it before either of us. But this very homology, if correct, indicates the probability of Mr. Binney's specimen being a fragment derived from the junction of stem and root rather than a true root, since in Jiving plants possessing a medullary sheath, that sheath, as every botanist knows, is never prolonged into the true roots, for the simple physiological reason that its origin is directly connected with that of the leaf formations of the ascending axis.

$\Lambda$ s I have already observed, M. Goeppert's and Mr. Binney's previous figures represent a structure altogether different from that now described by Mr. Binney. Instead of the continuous inner vascular cylinder of the latter, $M$. Goeppert's figure displays two detached, unsymmetrically arranged, vascular bundles in the interior of the medullary cavity. I have already affirmed my conviction that these belong to intruded rootlets of a Stigmaria, and are in no respects part of the true medullary axis. On the other hand, Mr. Binney says that "they are certainly not intruded rootlets, as anyone who examines the learned author's plates can satisly himself." On this point Mr. Carruthers writes to me on Nov. 2: "No one who is accustomed to sections of Stigmaria can fail to see that Goeppert has mistaken the accidental rootlets of Stigmaria penetrating the decayed axis for an organic part of that axis." I may allow this opinion of an experienced botanist, with which I wholly concur, to neutralise that of Mr. Binney, who further says: "It is vely improbable that they" (i.e., Goeppert's vascular rootlets) "had ever been int oduced into the axis after the pith had been removed." To this I reply that it is an extremely rare thing to find any such axis which does not contain more or less of these rootlets. My cabinet is full of such examples, and in two specimens on the table, one of which has been lent me by Capt. J. Aitken, of Bacup, similar rootlets not only exist in the central axis, but have penetrated the medullary rays as in M. Goeppert's specimen.

Mr. Binney, referring to my comments upon his previous memoir, says that in "that memoir mention is only made of the large vascular bundles found in the axis, without calling them vascular or any other vessels." I do not very clearly understand what this sentence means, but I presume it is intended to imp'y that Mr. Binney never affirmed that the pith of Stigmaria contained vascular tissues, and that I have misrepresented him in stating that he had done so. I can only answer this by giving Mr. Binney's words :- " The most important circumstance thus developed is the existence of a double system of vessels in Stig. maria, first shown by Goeppert, and the consequent approach in this respect to Diplexylon, Corda. In Diploxylon, however, the inner system forms a continuous cylinder, concentric with and in juxtaposition to the wodges of wood forming the outer; while in Stigmaria the same jnner system is broken tip into scattered bundles, apparently unsymmetrically arranged in the medullary axis or pith of the plant" (Quarterly Fournal of the Geological Society, vol. xv. p. I7) ; and on p. 78 of the same memoir, describing the specimen represented by Fig. 2 , he says, "The axis is filled with eleven or twelve large vessels of circular or oval form," and the same structures are again spoken of as "vessels" no less than six times in the next seventeen lines, with the further remark that "altogether these angular vessels remind me somewhat of the vascular tissue in the middle of Anabathra" (loc. cit., p. 78). It is true that in two places Mr. Binney applies to these structures the term "utricles," by which, I presume, he means cells; but such a term, applied to such tissues, is equally applicable to all known fibro-vascular structures, and is simply equivalent to saying that scalariform vessels have no existence.

I have entered into these details because by promulgating vague and groundless doubts respecting work alrcady carefully done, Mr. Binney's communication terds to re-introduce confusion into questions that rave been virtually settled. It does this through failing to discriminate between things that differ. His introductory remarks refer to the common Stigmaria ficoides, whilst his justification of those remarks rests upon a plant of a very different character, and which $\mathrm{I}$ am absolutely certain is not the common form of Stigmaria.

\section{VEGETATION OF THE LIBYAN DESERT}

IN Dr. Ascherson's report on the vegetation of the Libyan Desert, publis hed in the botanische Zeitung, there are some interesting notes on the fall and renewal of the leaves of deciduous trees. In our climate we have little difficulty in understanding the distinction between evergreen and deciduous trees and shrubs, because the greater part of those that change their leaves cast the old ones in autumn or carly winter; and evergreens with flat leaves have them more or less coriaceous. But even with us there is a gradual transition from evergreen to deciduous through Eunonymus curopous and Ligustrum vulgare, both of which have strictly evergreen congeners in Eunony'mus japonicus and Ligustrum japonicum. Some few years ago Hoffmann started a theory that sempervirence cuuld be artificially produced, and there is no doubt that climate influences to a great extent the length of the period during which really deciduous species hold their foliage; bat it appears far more probable that these are physiological peculiarities not altogether dependent upon climate, as we find evergreen and deciduous species growing in the same regions and under precisely similar conditions. Some evergreens do not change their leaves at all, and even retain them for many years or all their lifetime; Araucaria imbricata, for example. Iaxodium distichum, one of the few deciduous Coniferæ, offers a very curious phenomenon, inasmuch as the ultimate branchlets are deciduous. The observations chronicled by Dr. Ascherson agree almost entirely with our own experience. On his outward journey be traversed $25^{\circ}$ of lat. in less than a month, which gave him an excellent opportunity for studying the conditions of the same species under very diverse climates. Thus, in the plains of Lombardy many deciduous trees, and especially Morus alba, were still partially covered with foliage on the Igth 